\title{
PEMODELAN STRATEGI KAMPANYE SOSIAL PASCA PANDEMI COVID-19 BERBASIS 7 FASE KESEDIHAN KUBLER
}

\author{
Agung Eko Budiwaspada ${ }^{1}$, Alvanov Zpalanzani Mansoor ${ }^{2}$ \\ Institut Teknologi Bandung ${ }^{1}$, Institut Teknologi Bandung2
}

\begin{abstract}
Abstrak. Persebaran covid-19 berbanding lurus dengan kecepatan lalu-lintas orang dan barang era globalisasi. Menggali lebih dalam dampak sosial masyarakat terkait dengan pandemi covid-19, dapat dikonstruksi melalui tahapan emosional dalam kesedihan yang terjadi ketika manusia dihadapkan pada perubahan. Memahami dampak sosial pandemi covid-19 menghasilkan pengetahuan yang berguna untuk mengembangkan model strategi komunikasi persuasi publik Indonesia. Fenomena tersebut akan dipetakan dengan semiotika sosial untuk menghasilkan model siklus kesedihan pandemi covid-19 yang akan menjadi dasar pemodelan kampanye sosial. Adapun temuan dalam pengembangan model kampanye sosial pasca pandemi Covid-19 adalah perlunya membangun pemahaman akan khalayak sasaran melalui pengembangan pemahaman akan interaksi sosial budaya, dan pemahaman akan pola pengumpulan informasi, serta pemahaman akan sistem pengambilan keputusan khalayak sasaran berbasis konstruksi fase kesedihan pandemi covid-19. Pola perilaku, komunikasi dan interaksi sosial, serta pengambilan keputusan khalayak sasaran berbeda pada setiap fase kesedihan yang dialami. Oleh karena itu, 7 fase kesedihan pandemi covid-19 yang dilalui oleh khalayak sasaran merupakan pijakan penting dalam membangun pemahaman utama untuk memunculkan empati, sikap dan perilaku, serta tindakan dari khalayak sasaran sebagai tujuan dalam merancang kampanye sosial pasca pandemi Covid-19.
\end{abstract}

Keywords: Covid-19, Kampanye Sosial, Semiotika Sosial, 7 Fase Kesedihan, Desain Komunikasi Visual

Abstract. The vast spread of covid-19 is directly proportional to the spread of people and goods in the globalization era. Digging deeper into the social impact of the community associated with the covid-19 pandemic, can be constructed through emotional stages of sadness that occurs when humans are faced with sudden change. Understanding the social impact of covid-19 pandemic may develop insight that was useful for developing a model of Indonesia's public persuasion communication strategy. The above phenomenon will be mapped with social semiotics to produce a sadness cycle model which will become the basis for covid19 pandemic social campaigns model. The findings are needs to build an understanding of the target audience's socio-cultural interactions, understanding of patterns of information gathering, and understanding of the decision-making system based on the construction phase of the covid-19 pandemic pandemic sadness cycle. Behavioral patterns, communication and social interactions, and decision making of target audiences differ in each phase of sadness cycles. Therefore, the 7 phases of covid-19 pandemic sadness experienced by the target audience are important foothold in building primary understanding to bring empathy, attitudes and behavior, and actions of the target audience as objectives in the post-Covid 19 social pandemic campaign design.

Keywords: Covid-19, Social campaign, social semiotics, 7 phases of sadness, visual communication design

Correspondence author: Agung Eko Budiwaspada, agungebw83@yahoo.com, Bandung, Indonesia 


\section{Pendahuluan}

Istiah Covid-19 diambil dari kata Corona Virus Disease 2019, pertamakali dideklarasikan oleh Disease Prevention and Control (European Center of Disease Prevention and Control) pada akhir Desember 2019. Penyebab COVID-19 adalah sindrom pernafasan akut parah dari SARS CoV-2. Wabah Covid-19 diketahui berawal di Wuhan, provinsi Hubei, China. Dalam waktu yang cepat Covid-19 menyebar hampir di seluruh benua. Bagi orang berusia di atas 60 tahun yang memiliki penyakit penyerta, antara lain kardiovaskular, diabetes, penyakit pernafasan kronis, dan kanker, terinfeksi covid-19 memiliki resiko lebih parah, bahkan hingga kematian. Namun, tidak demikian bagi sebagian besar orang yang relatif masih muda dan sehat, terinfeksi virus COVID-19 hanya akan mengakibatkan gangguan pernafasan ringan hingga sedang dan bahkan bisa sembuh tanpa memerlukan perawatan khusus (self-limited disease). Jika demikian, mengapa covid-19 begitu ditakuti? Cara penyebaran yang mudah dan gejala terinfeksinya yang ringan tersebutlah justru membuat masyarakat kurang waspada dan menganggap remeh. Keterlenaan terjadi tidak hanya dikalanagan masyarakat, tapi juga alami oleh para pemangku kepentingan penanganan covid-19. Sikap yang demikian menjadi konduktor akselerasi penyebaran virus ini tidak hanya sebagai wabah, tapi hingga tingkat pandemi.

Hampir seluruh masyarakat dunia pada mulanya dibuat terkejut oleh kecepatan penyebaran pandemi covid-19. Persebaran covid-19 berbanding lurus dengan kecepatan lalulintas orang dan barang era globalisasi. Keterkejutan atas kenyataan yang jauh dari harapan bahwa pendemi ini nyatanya belum dapat dihentikan, membuat masyarakat berada di simpang jalan antara keterkejutan dan penyangkalan dengan berbagai alibi. Penyangkalan yang melampaui kemampuan bertahan dalam skala yang masif bertransformasi menjadi deprivasi massal dan memicu kepanikan dalam kefrustrasian (DuBois and Miley). Kondisi frustasi menstimulasi bangkitnya perilaku agresi. Titik terendah dampak pandemi covid-19 adalah kondisi psikologis yang mengarah terjadinya depresi sosial. Depresi merupakan satu masa terganggunya fungsi alam perasaan sedih yang berlebihan dan segala gejala penyertanya, termasuk perubahan pada pola psikomotor, konsentrasi, anhedonia, rasa putus asa dan tidak berdaya, bahkan hingga bunuh diri (Kaplan et al.). Dampak ini pada gilirannya akan menyentuh pada berbagai aspek kehidupan, yakni ekonomi, politik, sosial, dan budaya yang sengkarut.

Menggali lebih dalam dampak sosial masyarakat terkait dengan pandemi covid-19, dapat dikonstruksi melalui tahapan emosional dalam kesedihan yang terjadi ketika manusia dihadapkan pada perubahan. Perubahan yang sangat menyakitkan setara dengan seseorang yang sedang menghadapi sakratul maut. Elisabeth Kubler-Ross dalam bukunya "On Death and Dying" menjelaskan bahwa tahap-tahap kesedihan dapat ditransfer ke semua perubahan, tidak hanya pribadi tapi jauh lebih luas misalnya hingga ke persoalan psikologis massa. Disebutkan bahwa dalam setiap perubahan mengandung kehilangan. Disebutkan bahwa setiap perubahan mengandung kehilangan. Perubahan yang tidak sesuai dengan apa yang diinginkan akan menyisakan kesedihan. Apa yang diilustrasikan oleh Kübler dalam tujuh fase perubahan (the seventh stages of change) diperkirakan terjadi di masyarakat Indonesia dalam menghadapi dampak pandemi covid-19. Fenomena tersebut dapat dikenali melalui cara pandang interpretasi atas fakta sebagai teks. Berbagai media mentransmisikan pesan bahwa kasus terinfeksi covid19 di Indonesia menunjukkan kenaikan yang signifikan. Dalam waktu kurang dari satu bulan terpapar pandemi, kasus yang terinfeksi sudah hampir mencapai 3000 orang (Idhom). 


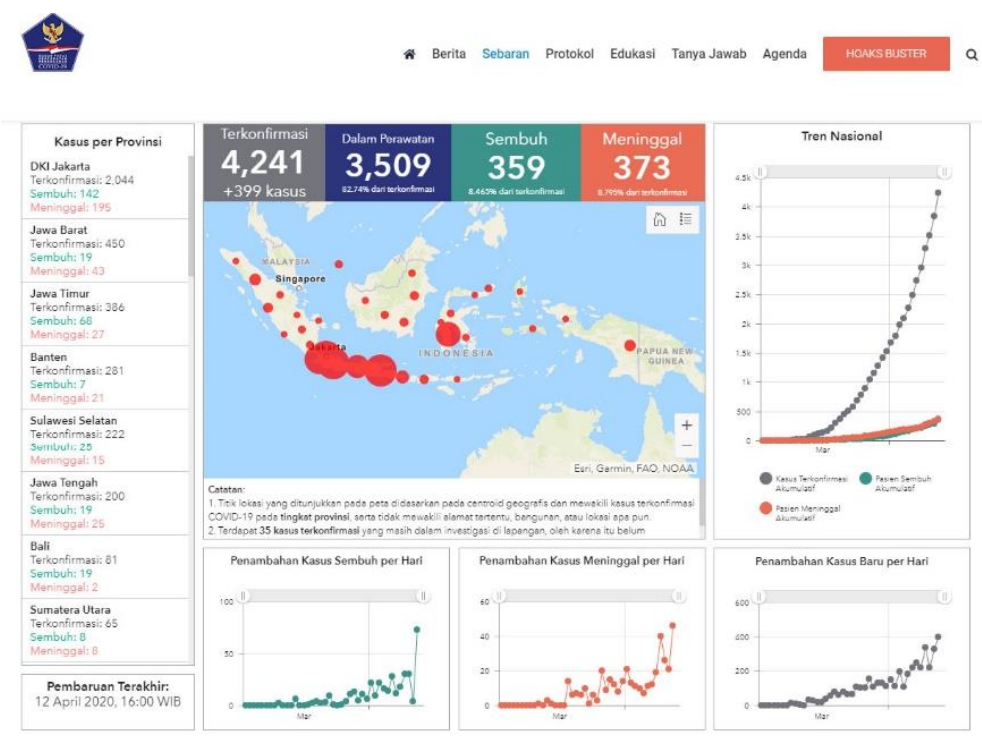

Gbr. 1. Dashboard Covid-19 situasi tertanggal 8 April 2020.

Sumber: Gugus Tugas Percepatan Penanganan Covid-19

Segala upaya penanggulangan pandemi covid-19 telah dilakukan oleh pemerintah. Seruan social distancing, stay at home, himbauan cuci tangan, menjaga kesehatan telah disampaikan kepada segenap masyarakat melalui berbagai kanal media. Tapi faktanya masih banyak masyarakat yang berperilaku tidak sesuai dengan seruan tersebut. Fakta ini melegitimasi angka keterjangkitan covid-19 dan mortalitas terus meningkat. Memang tidak mudah mempersuasi seluruh masyarakat Indonesia yang multi-etnik, multi-bahasa dan sekaligus secara georafis merupakan masyarakat kepulauan terbesar di dunia. Upaya memutus mata rantai pandemi covid-19 menjadi tantangan tersendiri bagi bidang persuasi publik. Lebih penting untuk dipikirkan, begitu pandemi covid-19 berakhir akan menyisakan kenangan mendalam tentang kesedihan yang terfragmentasi dalam 7 fase. Biasanya reaksi alami setelah terjadinya tragedi adalah trauma. Intervensi jangka pendek dibutuhkan apabila trauma tak kunjung trauma healing. Dalam jangka panjang, kenangan pandemi covid-19 akan mendorong terbentuknya gaya hidup baru. Gaya hidup tersebut akan memberikan pengkayaan khasanah dalam hal caracara, pranata, makna-makna di berbagai medan. Semuanya itu akan bertransformasi dalam sistem nilai kebudayaan, termasuk budaya persuai publik.

Kampanye adalah serangkaian tidakan komunikasi yang terencana dengan tujuan menciptakan efek tertentu kepada sejumlah besar khalayak yang dilakukan secara berkelanjutan pada kurun waktu tertentu (Rogers and Storey). Memahami dampak sosial pandemi covid-19 menghasilkan pengetahuan yang berguna untuk mengembangkan model strategi komunikasi persuasi publik Indonesia. Perlu diketahui dari banyak laporan penelitian, menegaskan bahwa kampanye yang dirancang dengan baik akan memberikan efek perubahan yang luar biasa pada khalayak sasarannya (Perloff). Fakta tersebut diperkuat oleh pernyataan bahwa kesuksesan (atau kegagalan) sebuah kampanye bergantung pada aspek perencanaan, implementasi, dan evaluasi menggunakan semua sarana ilmiah yang tersedia (Klingemann and Römmele). Fenomena inilah yang menyebabkan penulis melakukan tinjauan kritis terhadapnya.

Terkait dengan topik tersebut setidaknya ada dua persoalan dapat dirumuskan. Pertama, bagaimana memahami kondisi psikologis masyarakat dikonstruksi dalam 7 fase perubahan akibat dari pandemi covid-19? Kedua, bagaimana hasil konstruksi tersebut 
dimanfaatkan sebagai modalitas perancangan model strategi kampanye sosial pasca terjadinya tragedi?

Berdasarkan rumusan tersebut tinjauan kritis ini dengan sendirinya mengindikasikan tercapainya dua tujuan sebagai konsekuensi dari dua rumusan permasalahan yang dikemukakan. Dua tujuan yang dimaksud adalah 1) Mendapatkan pemaham tentang kondisi psikologis masyarakat dalam bingkai 7 fase kesedihan akibat dari pandemi covid-19. Kedua, menghasilkan rancangan model strategi kampanye sosial pasca terjadinya tragedi.

\section{Metode}

Dibutuhkan alat dan cara yang tepat untuk mencapai tiga tujuan tersebut. Dalam tinjauan kritis, tiga tujuan itu akan dapat dicapai setidaknya dengan menggunakan dua metode, yakni semiotika sosial (Halliday) dan pemodelan Kampanye (Ostergaard Venus et al.). Sumber semiotik dapat mencakup hampir semua hal yang memiliki makna secara sosial dan kultural, termasuk kondisi psikologis masyarakat akibat pandemi covid-19. Kondisi tersebut dapat diamati dari teks media sebagai wacana. Teks media mencakup medan wacana (filed of discourse), pelibat wacana (tenor of discouse), dan sarana wacana (mode of discourse). Ketiga komponen teks tersebut digali secara kualitatif melalui analisis isi informasi yang ditransmisikan melalui media pemberitaan pandemi covid-19. Berbagai sumber semiotik pandemi covid-19 selanjutnya dipilih secara purposif (criterion based) berdasarkan makna, citra, opini, dan motif dominan yang relevan kondisi psikologis dan perilaku dengan bingkai 7 fase perubahan, yakni: terguncang (shock), Penyangkalan (denial), frustrasi atau marah (anger), depresi (depression), percobaan (experiment), keputusan (decision or realization), dan integrasi (integration). Hasil identifikasi ini, selanjutnya direlasikan dengan jumlah dan/atau prediksi jumlah kasus terinfeksi pandemi covid-19 di Indonesia. Relasi ini akan memberi artikulasi dan penekanan makna pada narasi di setiap fase kondisi sosial tersebut. Semiotika sosial dimanfaatkan sebagai alat dan cara untuk mencapai tujuan pertama tinjauan kritis ini.

Untuk mencapai tujuan kedua, alat dan cara yang digunakan adalah adaptasi pemodelan Kampanye sosial Ostergaard. Alasan pemilihan model ini adalah karena variabelnya memiliki relevansi yang kuat dengan topik. Selain itu, model ini dinilai paling pekat persinggungan ilmiahnya dibanding dengan beberapa model kampanye sosial lainnya (Klingemann and Römmele). Ciri ilmiah ditunjukkan dari proses pemodelan yang dilandasi oleh cause and effect analysis, data, dan theoretical evidence (Venus et al.). Dalam model ini, variabel kampanye menjadi landasan 3 variable berikutnya, yakni: pengetahuan (knowledge), sikap (attitudes), dan kecakapan (skill). Pengetahuan, sikap, dan kecakapan akan menghasilkan perilaku (behavior) sesuai dengan tujuan kampanye sosial. Pemodelan dimulai dari identifikasi masalah. Dalam tinjauan kritis ini, permasalahan yang hendak dijadikan pijakan perancangan model strategi kampanye sosial adalah konstruksi fakta dan prediksi dampak psikologis pandemi covid-19 yang dibingkai oleh teori fase kesedihan Kubler (Kubler-Ross).

\section{Hasil dan Pembahasan}

Berangkat dari perspektif kondisi psikologis kesedihan, semiotika sosial, dan pemodelan kampanye sebagai pustaka pijakan utama dalam kajian kritis ini, semestinya perlu diuraikan secara komprehensif terhadap ketiganya, agar kajian terkerangkai secara utuh dan 
berhubungan satu dengan yang lainnya. Namun demikian, harus disadari bahwa uraian secara mendalam tidaklah memungkinkan dilakukan pada ruang yang terlalu sempit ini. Memberikan pemahaman teori yang lebih mendalam memerlukan wahana yang lebih memadai, bukan pada format tulisan pendek seperti ini. Oleh sebab itu, dalam kajian kritis ini terori-teori tersebut hanya ditinjau dari aspek terpenting dan relevan saja. Selanjutnya, secara aplikatif diturunkan ke hal-hal yang berkaitan dengan tahap dan strategi pembahasan sebagaimana dijelaskan berikut ini.

Identifikasi Kesedihan Akibat Pandemi Covid-19 dalam cara pandang Semiotika Sosial.

Kehilangan sesuatu yang bermakna bisa berpengaruh secara signifikan pada kehidupan manusia. Kehilangan menyisakan kesedihan yang mendalam, seperti kematian orang yang dicintai, kehilangan sesuatu yang berharga atau harapan yang oleh karena suatu hal terpaksa dikubur sedalam-dalamnya. Kesedihan melibatkan emosi dan menimbulkan reaksi bertahap. Berat atau ringannya reaksi emosi sederajat dengan tingkat kesedihan yang dialami. KublerRoss, menjelaskan fase perubahan atas kesedihan dalam the seventh stages of change.

Kajian ini mengkritisi setiap fase perubahan kesedihan melalui cara pandang menggunakan tiga komponen semiotika sosial. Ketiga komponen tersebut adalah: pertama, medan wacana (field of discourse) yang intensinya adalah untuk mengetahui apa yang menjadi wacana dominan media massa terkait kesedihan sebagai dampak pandemi covid-19. Medan wacana juga menyoroyi bagaimana wacana dominan tersebut diperlakukannya; kedua, adalah pelibat wacana (tenor of discourse), komponen ini berkepentingan untuk megetahui orangorang yang ada dalam teks media, serta apa kedudukan dan peranan mereka dalam penanganan pandemi covid-19. Pelibat wacana dikaji secara multisided yakni sebagai representasi pemerintah yang berperan sebagai pembuat kebijakan dan masyarakat sebagai pihak yang disasar kebijakan tersebut. Sarana wacana (mode of discourse), dihadirkan untuk memberi ilustrasi dan penekanan artikulasi pada narasi makna, citra, opini dan motif tentang medan dan pelaku wacana. Penekanan artikulasi diberlakukan pada setiap fase kesedihan. Sarana wacana yang berupa bahasa tanda dan kode, menjelaskan bagaimana pelibat wacana (pemerintahkomunikator) menggunakan gaya bahasa dan ekspresi sumber semiotik untuk menggambarkan medan wacana kepada pelibat di sisi lainnya (masyarakat-komunikan). Kerangka tinjauan kritis ini dipandu oleh diagram sebagai berikut.

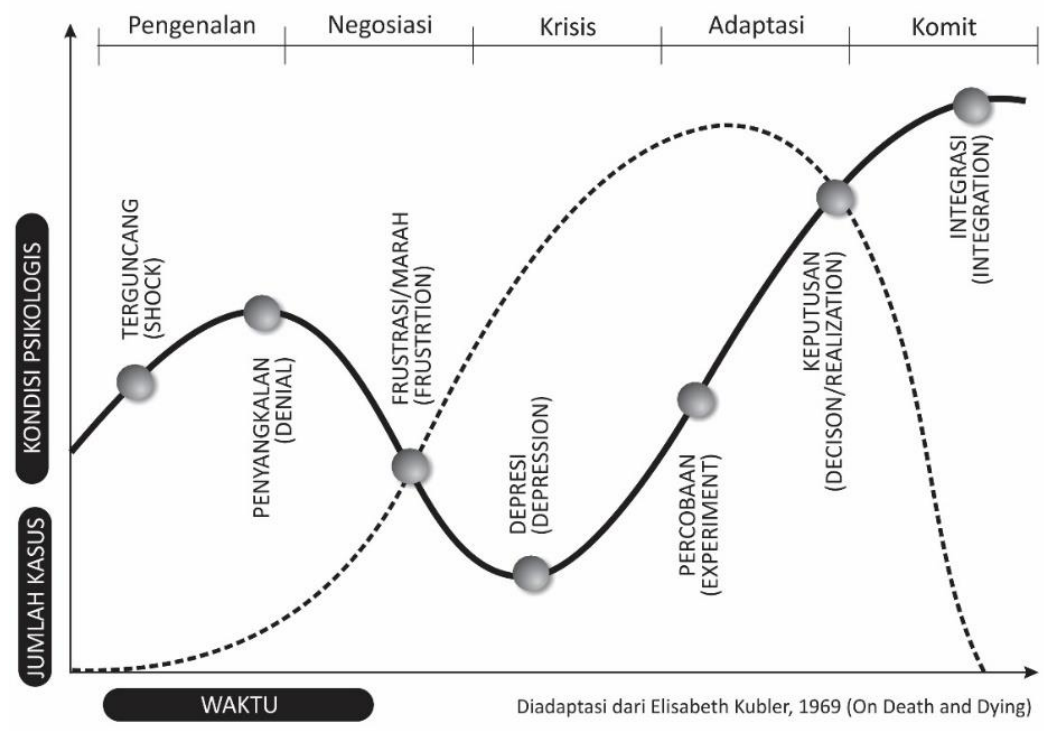

Gbr. 2. Grafik kesedihan masyarakat dan prediksi jumlah kasus covid-19 


\section{Kondisi Kesedihan Masyarakat Fase Terguncang (Shock)}

Fase terguncang (dan fase percobaan) merupakan perluasan teori Elizabeth Kubler-Ross menjadi 7 fase dari yang semula hanya 5 fase, yakni: penyangkalan, marah/frustrasi, depresi, penerimaan/keputusan, dan integrasi. Fase keterguncangan terjadi ketika sesorang menerima kabar mengejutkan yang tak pernah diduga akan terjadi. Pandemi covid-19 benar-benar menghadirkan keterkejutan pada Indonesia dan dunia (Bossack). Hadirnya medan wacana pada fase ini ditandai oleh pemberitaan tentang terjadinya kasus positif terinfeksi virus covid-19 pertama di Indonesia pada tanggal 02 Maret 2020. Pemberitaan tersebut menjadi wacana dominan media elektronik, cetak, dan media sosial. Padahal jumlah kasus positif terinfeksi covid19 hanyalah 2 orang, namun berita tersebut mengguncang kodisi psikologis masyarakat (ipnn.com).

Dalam keterguncangan tersebut presiden Jokowi dan meteri kesehatan Letjen TNI (Purn) Dr. dr. Terawan Agus Putranto bertindak sebagai pelibat wacana semiotika sosial pandemi covid-19 (Ihsanuddin). Mereka telah menjadi figur sentral teks media. Keduanya berkedudukan sebagai pemangku kepentingan utama dalam penanganan pandemi covid-19, dan berperan sebagai komunikator dan sekaligus memproduksi pesan yang didesiminasikan. Dalam konteks pelibat wacana pandemi covid-19, masyarakat menjadi komunikan yang terletak pada multi sided role on binary opposition, dan berperan mengkonsumsi pesan tentang deklarasi bahwa Indonesia akhirnya terjangkit covid-19 juga.

Pada komponen Sarana wacana, fase keterkejutan direfleksikan pada suasana yang terbangun dari cara-cara penyampaian medan wacana oleh pelibat wacana. Ekspresi wajah Presiden saat mempresentasikan sarana wacara pandemi covid-19, mentransmisikan pesan keterkejutan. Berulang kali disampaikan bahwa masyarakat agar tetap tenang dan tidak panik menghadapi kenyataan bahwa pandemi covid-19 telah menjangkit Indonesia. Repetisi narasi bahwa Covid-19 yang notabene dikatakan hanya sebagai self-limited disease, diartikulasikan kembali oleh menteri kesehatan (CNN Indonesia). Opini tersebut sejatinya merupakan bahasa tanda dan kode yang dilatari oleh motif untuk menekan tingkat keterkejutan. Kita menghasilkan sesuatu yang baru hanya dalam kondisi kita mengulang-ulang (Gilles Deleuze dalam Piliang). Semakin diulang opini tentang tidak berbahanya covid-19, telah memproduksi makna oposisional baru yakni pengingkaran terhadap keterguncangan.

\section{Kondisi Kesedihan Masyarakat Fase Penyangkalan (Denial)}

Pada fase ini, masyarakat yang masih merasa terguncang secara sadar tidak mau menerima kenyataan bahwa sesuatu yang menyedihkan telah terjadi. la masih menganggap semuanya akan baik-baik saja. Kabar duka yang diterimanya diarahkan menuju pada suatu kebohongan. Penyangkalan dilakukan untuk menghilangkan kesedihan dan upaya menghibur diri sendiri atas realitas yang terjadi. Kesedihan mendalam yang akan segera menimpa seakan menuju kesekaratan. Itu sebabnya reaksi spontan yang muncul adalah penyangkalan: "No, it can not be true! I don't believe it!". Secara psikologis, penolakan semacam ini merupakan bentuk mekanisme pertahanan mental untuk mengulur-ulur waktu agar tidak terpuruk oleh tekanan kabar buruk atas dirinya. Fase keterguncangan dan penyangkalan merupakan episode pengenalan dan negosiasi.

Medan wacana dominan penyangkalan terhadap kesedihan akibat pandemi dapat dikenali dari berita tentang kesembuhan 3 pasien pertama terinfeksi covid-19. Pada tanggal 16 Maret 2020, terkonfirmasi bahwa kasus positif terinfeksi covid-19 sebanyak 134 orang, dan meninggal hanya 5 orang. Berita tersebut memproduksi wacana bahwa covid-19 adalah virus yang tidak berbahaya dan tidak mematikan. Namun demikian, Presiden Joko Widodo melalui 
pidatonya terkait dengan penanganan penyebaran dan dampak Covid-19 pada Minggu 15 Maret 2020 menghimbau diterapkannya kebijakan social distancing. Paradoks ini mengukuhkan telah hadir fase penyangkalan.

Pada fase ini, menteri kesehatan tampil sebagai pelibat wacana utama dan mendapat semacam endorse dari ketiga pasien yang telah dinyatakan sembuh tersebut berkedudukan sebagai pelibat wacana pendukung. Mereka berperan mengirim pesan kepada masyarakat bahwa covid-19 dapat disembuhkan. Sementara itu para pejabat tinggi di negara, para menteri, dan para kepala daerah berperan berkedudukan sebagai pelibat wacana yang berperan mendiseminasikan himbauan social distanding (Prireza). Sarana wacana diamplifikasikan melalui kode berupa pemberian bingkisan kado jamu tradisional dari presiden kepada ketiga pasien yang sembuh (Qodar). Kado tersebut secara konotatif mengandung kode budaya agar masyarakat tetap menjaga kesehatan, dan sekaligus menyangkal bahwa virus ini membahayakan. Wacana dominan yang diproduksi adalah tidak mengakui realita bahwa covid19 dapat menginfeksi siapa pun secara cepat dan luas. Stimulus yang diproduksi oleh pelibat sebagai medan wacana, direspons oleh masyarakat dalam bentuk representasi mental (citra). Dalam respons tersebut terjadi proses psikodinamis yang melibatkan persepsi, kognisi, motivasi dan sikap individu - sebagai bagian dari masyarakat - justru menghadirkan penyangkalan bahwa pandemi covid-19 tidak berbahaya. Masyarakat mengamati dan melakukan proses pemaknaan (persepsi) berdasarkan pengalaman terhadap beragam konten medan wacana tentang pandemi covid-19 di seluruh dunia menghasilkan pengetahuan (kognisi) untuk menggerakkan dirinya (motivasi) agar tetap berpikiran tenang dan bertindak waspada (sikap). Representasi mental yang demikian telah mengokohkan indikasi adanya upaya-upaya penyangkalan terjadinya tragedi kemanusiaan yang berskala global.

\section{Kondisi Kesedihan Masyarakat Fase Frustrasi (Frustration-Anger)}

Setelah melewati episode pengenalan dan negosiasi, kondisi mental masyarakat mulai memasuki masa-masa krisis, yakni berada pada fase frustrasi. Fase ini menimbulkan kemarahan sebagai wujud ekspresi ketidakberhasilan melawan penyangkalan atas penderitaannya. Masyarakat marah karena hal-hal buruk terjadi padanya dan merasa bahwa peristiwa yang terjadi berlaku tidak adil. Bahkan mereka marah pada keadaan dan berpikir bahwa ada pihakpihak yang telah berlaku sangat jahat kepadanya. Pada gilirannya tumbuh rasa frustrasi, kemarahan, dan berbalik menyalahkan diri sendiri.

Dalam konteks semiotika sosial, medan wacana fase frustrasi ditandai oleh kebijakan pembatasan sosial bersekala besar (PSBB) di DKI pada tanggal 10 April 2020 (Umasugi). Pada saat itu, terkonfirmasi bahwa kasus positif terinfeksi covid-19 sebanyak 3512 orang, sembuh sebanyak 282 orang, dan meninggal sebanyak 306 orang. Ada kecenderungan bahwa kebijakan ini akan meluas ke beberapa provinsi yang dianggap sebagai klaster yang memiliki titik penyebaran penularan Corona COVID-19. Permasalahan pandemi ini semakin serius dan meluas secara masif, untuk mengatasinya Presiden Joko Widodo pada tanggal 13 maret 2020 membentuk Gugus Tugas Percepatan Penanganan Covid-19 di Indonesia, yang diketuai oleh Doni Monardo dengan juru bicara Achmad Yurianto (Bayu). Kedua figur ini selanjutnya sering menjadi pelibat wacana utama berkedudukan sebagai pelaksana penanganan pandemi covid19 di Indonesia. Dalam konteks ini - termasuk presiden tantunya - mereka berperan memproduksi pesan-pesan sebagai panduan operasional bagi segenap pemangku termasuk para kepala daerah, para tenaga medis dan masyarakat.

Sarana wacana pada esensinya dapat dibaca sebagai isyarat untuk mencegah kepanikan di berbagai sendi kehidupan dengan cara menegakkan kedisiplinan dalam 
menjalankan protokol covid-19. Pemberlakuan pembatasan sosial berskala besar membawa konsekuensi terjadinya pengekangan ruang gerak masyarakat. Berbagai insentif diberikan oleh pemerintah sebagai stimulus guna mengatasi penderitaan masyarakat. Pemerintah mengalokasikan anggaran sebesar Rp 405 triliun untuk mengatasi dampak covid-19 di Indonesia (Sari). Pelonggaran pajak, stimulus Kredit Usaha Rakyat, restrukturisasi kredit, penghapusan iuran BPJS tenaga kerja, bantuan social safety net kepada masyarakat kecil, kartu sembako, keringanan tarif listrik, mempercepat pencairan bantuan program keluarga harapan, bantuan pangan non-tunai, dan bantuan langsung tunai menjadi medan wacana media. Stimulus yang diberikan terkonsentrasi pada upaya mengatasi kondisi adanya Covid-19. Dalam konsep economic analysis of law (Coase) idealnya paket stimulus yang demikian akan lebih efektif jika ditujukan bagi pemulihan akibat dari dampak pandemi. Upaya sungguhsungguh pemerintah demi meringankan kesedihan masyarakat, ironisnya, tidak diimbangi oleh perilaku masyarakat yang kondusif. Masih banyak ditemui aktivitas masyarakat seolah berada dalam situasi normal. Sebagian darinya kurang mengindahkan regulasi pembatasan sosial berskala besar. Mangapa demikian? Menghabiskan waktu di rumah dengan tidak adanya kepastian kapan isolasi diri ini akan berakhir, membuat mereka stres. Himpitan ekonomi bagi masyarakat tidak mampu, menambah kesengsaraan dan kesedihan yang mendalam sehingga mudah marah. Mereka merasa berada di situasi menyakitkan yang disebabkan oleh kelalaian orang lain. Mereka menjadi penonton gejala aksi rush buying yang dilakukan sebagian kalangan masyarakat mampu. Pada puncaknya - dalam kemungkinan terburuk - pada fase ini dapat saja terjadi penjarahan sebagai ekspresi kefrustrasian. Diketahui bahwa frustrasi dapat menimbulkan keinginan bertindak untuk menyakiti yang mengarah pada sumber-sumber eksternal. Keinginan tersebut pada gilirannya mampu memicu timbulnya perilaku agresi secara nyata (Krahe dalam Hanurawan). Gejala ini dapat diidentifikasi melalui pernyataan Kapolda Jateng yang menemukan setidaknya hampir 800 ribu situs yang isinya memprovokasi masyarakat untuk melakukan penjarahan (Gumilang).

\section{Prediksi Kondisi Kesedihan Masyarakat pada episode krisis, adaptasi dan komit}

Episode krisis menjadi titik terendah kondisi mental dan kesedihan seseorang pasca kegagalan bernegosiasi dengan kefrustrasian. Pada episode ini terjadi fase depresi (depression). Fase dimana seseorang dengan sendirinya akan memasuki perasaan kosong. Disebutkan bahwa depresi merupakan satu masa terganggunya fungsi manusia yang berkaitan dengan alam perasaan yang sedih dan gejala penyertanya, termasuk perubahan pada pola tidur dan nafsu makan, psikomotor, konsentrasi, anhedonia, kelelahan, rasa putus asa dan tidak berdaya, bahkan hingga bunuh diri (Kaplan et al.). Dalam skala yang luas, depresi terjadi di masyarakat sebagai akibat dari pencegahan penyebaran covid-19. Masyarakat depresi karena terpapar medan wacana media secara intensif memberitakan jumlah kasus pandemi yang terus meningkat menuju puncaknya. Meskipun mereka menyaksikan berbagai upaya telah dilakukan oleh pelibat wacana untuk menekan persebaran covid-19, namun hasilnya tetap tidak dapat memenuhi harapan. Kondisi ini menimbukan kecemasan dan ketakutan, terutama jika ada kemungkinan mereka tertular infeksi covid-19. Pada saat yang bersamaan, kondisi sosial ekonomi yang terganggu serta berbagai perkembangan informasi di media yang menimbulkan berbagai narasi yang memperparah rasa cemas dan takut di masyarakat (Prabowo). Pada titik ini, mereka hanya bisa diam di tingkat kesedihan yang paling dalam. Masyarakat mengurung diri atau menutup hati untuk beberapa saat. Kondisi ini justru kondusif untuk memutus mata rantai covid-19 dan menjadi titik balik kondisi psikologis masyarakat ke arah yang positif. Mereka mulai menyadari bahwa kesedihan yang berlarut-larut tidak ada gunanya dan mempertimbangkan 
untuk melanjutkan hidup. Hal ini ditandai dengan munculnya tagar \#Indonesia Terserah di media sosial.

Masyarakat mulai beradaptasi terhadap kesedihannya, dan mulai bereksperimen sebagai pribadi-pribadi penyintas (survivor) dan memasuki episode adaptasi fase percobaan (experiment). Masyarakat mencari solusi dengan cara dan kemampuan masing-masing untuk keluar dari persoalan kehidupannya. Mereka mencoba melakukan adaptasi untuk meningkatkan kondisi psikologisnya berbasis protokol covid-19. Mereka tidak lagi menyalahkan diri sendiri, orang lain atau keadaan. Sikap yang demikian mendorong emosinya menuju kekondisi yang cenderung lebih stabil. Secara perlahan mulai dapat menerima kenyataan, walau sesekali kesedihan masih muncul kembali. Pikiran mulai jernih dan bisa beradaptasi dengan pola kehidupan di tengan pandemi covid-19. Masyarakat mendapati stimuli medan wacana tentang kasus terinfeksi covid-19 telah berada pada puncaknya. Trend penurunan jumlah kasus baru mulai terlihat dan jumlah kesembuhan penderita covid-19 semakin meningkat. Secara alamiah masyarakat mulai menerima perubahan dan berada pada akhir episode adaptasi, yakni fase keputusan (decision/realization).

Kesedihan masayarakat menghadapi pandemi covid-19 memasuki episode akhir, yakni komit yang artinya mereka telah berapada pada fase integrasi (integration). Dicapainya fase integrasi bukan berarti begitu saja menghapus kesedihan pada fase sebelumnya. Kesedihan yang dulu dirasa berat, kini tak terasa seberat dulu. Pandemi covid-19 yang semakin menghilang, secara berangsur mengantarkan masyarakat pada kondisi yang benar-benar sudah bisa menerima kenyataan. Kesedihan yang dirasakan tidak lagi menyakitkan tapi menjadi energi pendewasaan. Fase integrasi ini terjadi ditandai oleh medan wacana yang memberitakan bahwa sudah tidak ada lagi kasus baru covid-19. Kesedihan sepanjang episode covid-19, dalam jangka panjang akan ditransformasikan salah satunya menjadi sistem nilai baru dalam budaya pendidikan generasi Covid-19.

Dalam kebudayaan baru tersebut, pendidikan akan digeser menuju orientasi budaya substanstif dari tradisi seremonial kelas. Institusi pendidikan yang sebelumnya menciptakan sistem yang kurang siap terhadap pandemi covid-19 dan segala resesi yang menyertainya, segera mendorong terjadinya evolusi menjadi budaya baru berbasis virtual learning. Pandemi ini telah memberi pelajaran berharga, dan institusi pendidikan memetik pelajaran itu. Institusi pendidikan menata ulang proses-proses dan unit-unit sebagai tempat produksi kuasa tradisi lama. Dengan sendirinya yang tidak substansial akan menjadi tidak relevan. Generasi muda yang selama ini menghabiskan banyak waktu di kelas akan memiliki kesempatan lebih luas untuk bersosialisasi dengan lingkungan realita yang lebih luas di luar kelas. Di sisi yang sebaliknya, secara domestik mereka berkesempatan menghangatkan kembali hubungan kekeluargaan dan kekerabatan dengan orang-orang terdekat, menikmati hasil reduksi alokasi waktu untuk mengakses pembelajaran yang selama ini menyitanya. Jika hal ini terjadi, artinya pandemi covid19 dapat dipandang sebagai momentum peremajaan sistem pengajaran di institusi pendidikan.

Generasi muda sebagai stake holder utama pendidikan mendapatkan modalitas baru dari pengalaman isolasi di rumah selama menjalani fase-fase pandemi covid-19. Mereka adalah generasi muda baru yang telah berhasil mengatasi masa-masa kebosanan. Hal ini memupus stigma bahwa mereka adalah individu yang mudah menyerah, instan, serta temperamental. Home isolation telah memaksa mereka untuk membangun pagar pemisah dengan sebayanya. Pada masa sebelumnya segala persoalan sekecil apa pun diselesaikan bersama sebayanya sebagai wujud relasi sosial. Pada masa sebelumnya pagar pemisah itu terbangun dan membatasi relasi antar generasi, termasuk dalam ranah domestik keluarga. Tanpa disadari, karantina mandiri di rumah akan menjadikan mereka sebagai generasi penyambung gap dari generasi 
sebelumnya, yakni orang tua mereka. Inilah arketip (archetype) generasi baru, generasi produk pandemi covid-19.

Makna ini, esensi dari rangkaian kajian kritis yang mengkonstruksi kesedihan sosial dan perlu disosialisasikan dengan pemodelan kampanye sosial dengan scientific approach.

Pemodelan Strategi Kampanye Sosial Pasca Pandemi Covid-19 melalui adaptasi cara pandang Ostergaard

Kampanye adalah serangkaian tidakan komunikasi yang terencana dengan tujuan menciptakan efek tertentu kepada sejumlah besar khalayak yang dilakukan secara prsuasif dan berkelanjutan pada kurun waktu tertentu (Rogers and Storey). Aktivitas persuasif tersebut dapat digunakan untuk berbagai motif atau tujuan. Apakah itu aktivitas persuasi yang bertujuan memunculkan kebutuhan akan suatu hal yang disebut kampanye marketing, ataupun persuasi yang bertujuan untuk mengubah cara pandang, sikap, kebiasaan, maupun perilaku sasarannya yang disebut dengan kampanye sosial (Andrews). Kata persuasi perlu digarisbawahi karena adanya upaya mempengaruhi massa atau sasaran lebih dari sekedar memberitahu atau memberi wawasan maupun informasi.

Menurut Oostergard (dalam Venus et al.) langkah awal yang harus dilakukan dalam mengembangan sebuah kampanye adalah identifikasi permasalahan untuk mendapatkan hubungan sebab-akibat (cause-effect relationship) berdasarkan fakta yang ada. Langkah berikutnya adalah pengelolaan kampanye yang terdiri atas perancangan, pelaksaaan, dan evaluasi. Evaluasi merupakan telaah atas kampanye yang sudah dikelola apakah memberikan dampak yang positif seperti mereduksi permasalahan yang teridentifikasi, kurang efektif, atau bahkan memperburuk.

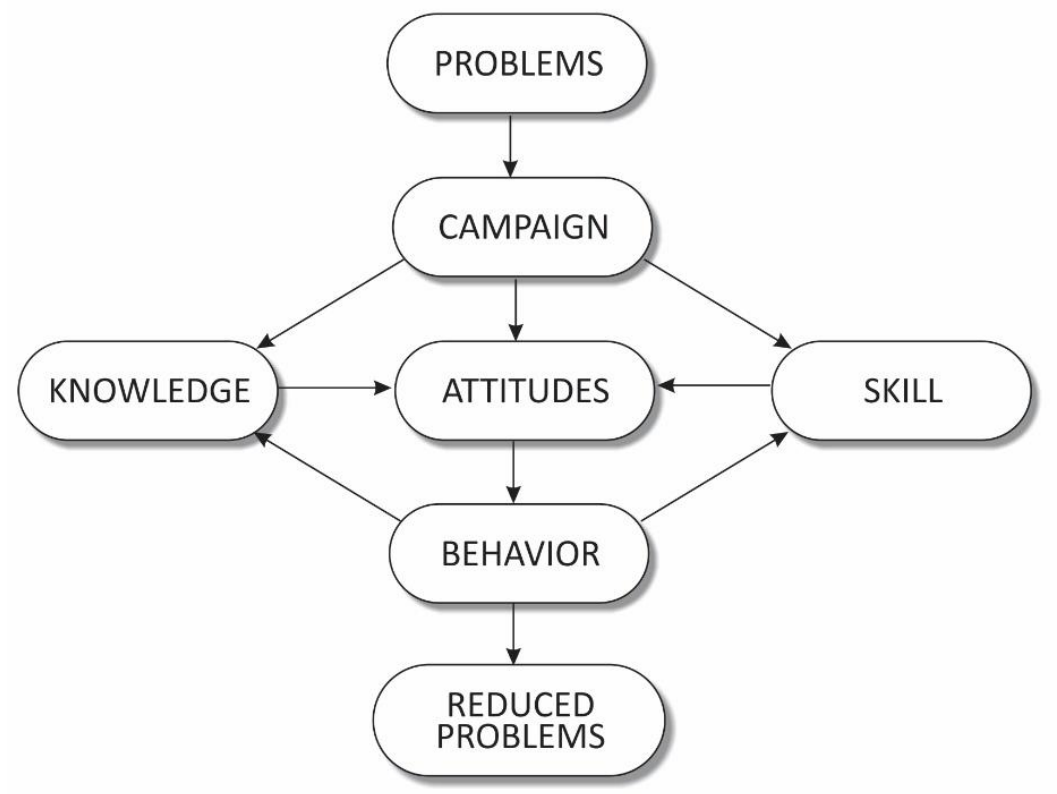

Gbr. 3. Model kampanye Oostergard (Venus, 2004)

Membangun Pemahaman akan Khalayak Sasaran dalam Kampanye Sosial Pasca Pandemi Covid19 melalui 3 wawasan

Pada konteks konstruksi kesedihan dampak pandemi Covid-19, identifikasi permasalahan semakin kompleks seiring dengan dinamika fase kesedihan yang dilalui. Berbagai disiplin ilmu dapat menjadi titik awal acuan sebagai dasar permasalahan untuk mengawali 
sebuah kampanye sosial. Akan tetapi pada akhirnya akan mengerucut pada satu hal yang harus dapat dipetakan terlebih dahulu, yakni bagaimana mengidentifikasikan permasalahan pada khalayak sasaran. Dalam mengidentifikasikan permasalahan sebenarnya, perlu adanya pemahaman akan bagaimana dinamika interaksi sosial budaya yang terjadi di masyarakat. Data demografis dan psikografis saja tidak dapat dijadikan acuan untuk mengidentifikasikan khalayak sasaran. Untuk membangun pemahaman akan khalayak sasaran sebagai subjek penerima pesan kampanye sosial perlu mendapatkan wawasan akan cara mereka berinteraksi dengan sesama, bagaimana cara mereka melihat relasi dan hierarki mereka dalam jejaring sosial yang mereka masuki, dan bagaimana pengambilan keputusan dilakukan dalam sistem tersebut. Adapun pemetaan dari ketiga wawasan tersebut adalah sebagai berikut.

1. Wawasan akan Pola Interaksi Sosial Budaya Khalayak Sasaran

Pola interaksi sosial budaya khalayak sasaran dapat dipahami melalui pemetaan akan nilainilai yang mempengaruhi interaksi sosial khalayak sasaran. Nilai yang umum dijadikan acuan adalah nilai budaya dan tradisi, serta nilai religi.

2. Wawasan akan Pola Pengumpulan Informasi Khalayak Sasaran

Pola pengumpulan informasi khalayak sasaran dipengaruhi oleh bagaimana pola komunikasi yang dibangun oleh khalayak sasaran. Bagaimana khalayak sasaran menerima dan meyakini sebuah informasi. Menerima informasi dengan meyakini informasi sebagai sebuah fakta. Akan tetapi, inti dari pola pengumpulan informasi khalayak sasaran adalah memetakan bagaimana khalayak sasaran membangun pola pengumpulan informasi. Pola pengumpulan informasi ini mempengaruhi perancangan strategi komunikasi dalam kampanye sosial dan pola penyajian informasi dalam sebuah media. Pola dasar penyajian informasi komunikasi yakni AIDA (Awareness, Interest, Desire, dan Action) dikembangkan oleh E. St. Elmo Lewis pada tahun 1898 sebagai pedoman dalam komunikasi penjualan (Kottler et al., 2019) berkembang berbasis keaktifan khalayak sasaran dalam mencari informasi dan salah satu pengembangan yang umum dirujuk adalah AISAS (Awareness, Interest, Search, Action, dan Share) yang dikembangkan oleh Dentsu.

3. Wawasan akan Pola Pengambilan Keputusan Khalayak Sasaran

Pola pengambilan keputusan khalayak sasaran dipengaruhi oleh hierarki sosial dan pola pengumpulan informasi. Pengambilan keputusan sangat dipengaruhi oleh tingkat kepercayaan khalayak sasaran pada kanal informasi di sekitarnya. Pemetaan atas hierarki sosial khalayak sasaran akan dapat mengidentifikasikan siapa yang memilliki peran penting untuk mempengaruhi pengambilan keputusan khalayak sasaran. Adapun pemetaan akan pola pengumpulan informasi khalayak sasaran akan dapat mengidentifikasikan kanal media mana yang paling berpengaruh. Pola pengambilan keputusan khalayak sasaran ini mempengaruhi perancangan strategi dan pola integrasi media dalam kampanye sosial.

\section{Pengaruh 7 Fase Kesedihan Pandemi Covid-19 pada Khalayak Sasaran}

7 Fase kesedihan pandemi Covid-19 merupakan konstruksi dinamis aspek emosional, persepsi, sosial, dan budaya khalayak sasaran yang akan mengubah pemahaman akan khalayak sasaran pada 3 wawasan, yakni pola interaksi sosial budaya, pola pengumpulan informasi, dan pola pengambilan keputusan. Pandemi Covid-19 mengubah praktek interaksi sosial budaya masyarakat global dengan paksa. Akan tetapi perubahan tersebut tidak terjadi secara serentak dalam waktu yang bersamaan akan tetapi bertahap dan berkelanjutan seperti dalam 7 fase kesedihan Kubler. Setiap tahap dalam 7 fase kesedihan akibat pandemi covid-19 akan 
mengonstruksi emosi, persepsi, dan sikap yang berbeda pada khalayak sasaran. Pada tahap berikutnya, konstruksi emosi, persepsi, dan sikap yang muncul terhadap pandemi Covid-19 akan mempengaruhi pola interaksi sosial budaya, pola pengumpulan informasi, dan pola pengambilan keputusan khalayak sasaran. Pada sejumlah media terdapat liputan yang menunjukkan beragam sikap masyarakat yang mengindikasikan beragam fase kesedihan yang dilalui. Oleh karena itu, kampanye sosial yang disampaikan pada satu kelompok khalayak sasaran yang sama, tidak dapat digunakan pada setiap fase kesedihan pandemi Covid-19. Begitu pula konsekuensinya, kampanye sosial yang dikembangkan pada fase tertentu tidak dapat diterapkan pada khalayak sasaran secara luas.

\section{Rekomendasi Model Strategi Kampanye Sosial (Pasca) Pandemi Covid-19}

Oostergard menyatakan bahwa kampanye akan mempengaruhi 3A, yakni Awareness, Attitude, dan Action. Akan tetapi wawasan akan emosi, persepsi, dan interaksi sosial khalayak sasaran dalam konteks pandemi covid-19 tidak dapat digeneralisasikan secara demografis, psikografis, dan geografis semata. Akan tetapi fase dalam konstruksi kesedihan covid-19 dapat menjadi acuan dalam mengembangkan wawasan akan khalayak sasaran untuk mengidentifikasi permasalahan kampanye sosial yang berikutnya akan memunculkan tujuan kampanye yang jelas dan terarah bagi perancangan dan pengelolaan kampanye sosial (lihat gambar 4).

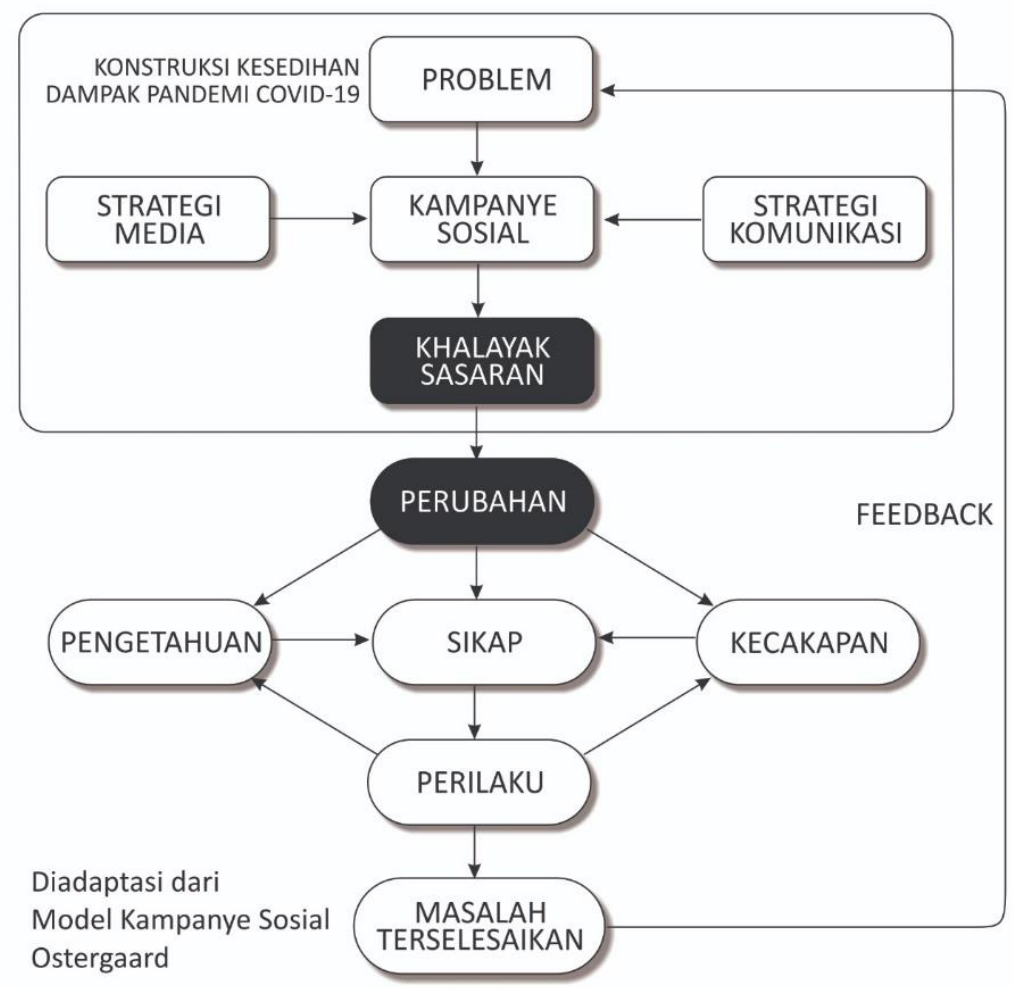

Gb. 4. Model Strategi Kampanye Sosial Pandemi covid-19

Konstruksi kesedihan dampak pandemi covid-19 menjadi titik tolak yang mendasari identifikasi masalah kampanye sosial yang berbasis pada pemetaan 3 wawasan khalayak sasaran, yakni pola interaksi, pola pengumpulan informasi, dan pola pengambilan keputusan. Identifikasi masalah yang tidak tepat akan menghasilkan kampanye sosial yang kurang berdampak atau bahkan sebaliknya memberikan efek negatif kepada pembuat kampanye. 
Sebagai contoh, kampanye eksperiensial solidaritas atas social distancing yang dilakukan oleh McDonald's Brazil memunculkan kemarahan netizen yang mengakibatkan McDonald's harus meminta maaf kepada khalayak sasaran dan menarik semua materi kampanyenya (Piper). Hal tersebut karena khalayak sasaran (Brazil) masih berada dalam fase terguncang dan penolakan, di mana mereka membutuhkan dukungan riil ketimbang dukungan moril (logo solidaritas). Khalayak sasaran mengharapkan dukungan logistik yang memberikan keuntungan finansial maupun non finansial. Akan tetapi yang dikampanyekan oleh McDonald's Brazil adalah perubahan logo yang diikuti perubahan layanan dari makan di tempat ke layanan antaran, bawa pulang, dan drive through tanpa ada keuntungan finansial maupun non-finansial (beneficial) bagi konsumen seperti penawaran paket khusus dan jaminan sosial ekonomi bagi pegawainya.

Dengan pemetaan wawasan khalayak sasaran yang berbasis fase kesedihan pandemi covid-19, tujuan dari kampanye sosial yang dirancang, yakni perubahan akan pengetahuan, sikap, dan kecakapan, yang berakhir pada perubahan pada perilaku yang lebih unik dan spesifik akan lebih mudah didefinisikan. Upaya mempersuai agar terjadi perubahan perilaku mensyaratkan adanya kedekatan kultural. Local wisdom, manifested through ideas about the daily behavior of target audiences, advertising that utilize existing assets in the environment around target audiences, and ideas that contain the value of tradition from their target audiences (Budiwaspada and Fadillah). Hal sebaliknya, tujuan kampanye yang tidak tercapai bisa dihindari karena adanya jarak yang lebar antara pesan kampanye dengan insihgt khalayak sasarannya.

\section{Simpulan}

Kampanye sosial adalah tindakan komunikasi persuasif yang bertujuan akhir untuk mengubah cara pandang, yang kemudian dapat berlanjut menjadi perubahan dalam sikap atau perilaku, dan pada akhirnya melakukan suatu hal yang dianjurkan dalam pesan kampanye. Dalam mengelola kampanye sosial, tahap identifikasi permasalahan dibagi menjadi 3 kunci pokok, yakni pemahaman akan khalayak sasaran melalui pengembangan pemahaman akan interaksi sosial budaya, dan pemahaman akan pola pengumpulan informasi, serta pemahaman akan sistem pengambilan keputusan khalayak sasaran. Adapun dalam tahap pengembangan kampanye sosial, dibutuhkan kemampuan untuk mengolah pemahaman akan 3 aspek tersebut menjadi sebuah sistem pesan persuasi yang disematkan pada seperangkat media secara terintegrasi dengan tujuan yang spesifik.

Perlu diperhatikan bahwa pemahaman akan 3 aspek khalayak sasaran merupakan fakta yang bersifat dinamis dan bergerak berdasarkan sebuah siklus tertentu. Pemahaman akan siklus yang dialami oleh khalayak sasaran tersebut akan meningkatkan probabilitas dari tercapainya tujuan kampanye sosial selain kompetensi mengemas pesan kampanye sosial melalui seperangkat media yang saling terintegrasi dengan baik dalam rentang waktu tertentu.

Dalam konteks pengembangan pemodelan strategi kampanye sosial pasca pandemi Covid-19, aspek siklus emosi, persepsi, sosial, dan budaya khalayak sasaran menjadi titik tolak penting dalam pengembangan identifikasi masalah dan pengelolaan kampanye sosial agar tepat pada sasaran dan memberikan dampak yang diharapkan. 7 fase kesedihan dampak Covid-19 yang berbasis pada fase kesedihan Kubler yang dikonstruksi melalui semiotika sosial merupakan model siklus dinamika emosi, persepsi, sosial dan budaya khalayak sasaran dapat menjadi acuan untuk pengembangan identifikasi permasalahan kampanye sosial terkait covid-19 maupun pasca pandemi covid-19. Fase kesedihan yang dialami oleh khalayak sasaran merupakan pijakan 
untuk membangun pemahaman utama untuk mengembangkan kampanye sosial pasca pandemi Covid-19 untuk membangun empati, sikap dan perilaku, serta tindakan dari khalayak sasaran.

\section{References}

Andrews, Marc. "Social Campaigns, Art of Visual Persuasion Its Psychology, Its Semiotics, Its Rhetoric." MaHKU-Utrecht Graduate School of Visual Art and Design, vol. MA, Thesis, HKU University of the Arts Utrecht, 2008. http://www.mahku.nl/download/m andrews socialcampaigns.pdf.

Bayu, Dimas Jarot. "Jokowi Bentuk Gugus Tugas Percepatan Penanganan Covid-19." katadata.co.id, 13 Maret 2020. https://katadata.co.id/agustiyanti/berita/5e9a4214bc69e/jokowi-bentuk-gugus-tugaspercepatan-penanganan-covid-19.

Budiwaspada, Agung Eko and Fadillah. "Locality Value as a Reflection of Core Values Incorporate Culture: A Study of Local Advertising Agency (Petakumpet)." Jurnal Sosioteknologi, vol. 17, no. 2, 2018, pp. 228-235, doi:http://dx.doi.org/10.5614\%2Fsostek.itbj.2018.17.2.5.

CNN Indonesia. "Menkes: Virus Corona Penyakit Yang Bisa Sembuh Sendiri." CNN Indonesia, 2 Maret 2020. https://www.cnnindonesia.com/nasional/20200302162005-20479814/menkes-virus-corona-penyakit-yang-bisa-sembuh-sendiri

CNN Indonesia. "Menkes: Jangan Panik Hadapi Virus Corona." 2020. https://www.youtube.com/watch?v=E3awGck2B2w, 15 April 2020.

Coase, Ronald H. "The Institutional Structure of Production." University of Chicago Law School, 1992.

Direktorat Sistem dan Teknologi Informasi ITB. "Peneliti Itb Buat Pemodelan Prediksi Puncak Penyebaran Covid-19 Di Indonesia." Institut Teknologi Bandung, 18 Maret 2020. https://www.itb.ac.id/news/read/57444/home/peneliti-itb-buat-pemodelan-prediksipuncak-penyebaran-covid-19-di-indonesia.

DuBois, Brenda and Karla Krogsrud Miley. Social Work: An Empowering Profession. Pearson, 2019.

European Center of Disease Prevention and Control. "Disease Background of Covid-19." European Centre for Disease Prevention and Control, 8 April 2020. www.ecdc.europa.eu/en/2019-ncov-background-disease.

Gugus Tugas Percepatan Penanganan Covid-19. "Situasi Virus Corona." Covid19.Go.id, 2020. https://www.covid19.go.id/situasi-virus-corona/

Gumilang, Akhtur. "Polda Jateng Blokir Ratusan Akun Medsos Sebar Provokasi Kerusuhan, Salah Satunya Kerusuhan 18 April." Tribun Jateng, 15 April 2020. 
https://jateng.tribunnews.com/2020/04/15/polda-jateng-blokir-ratusan-akun-medsossebar-provokasi-kerusuhan-salah-satunya-kerusuhan-18-april

Halliday, M. A. K. Language as Social Semiotic: The Social Interpretation of Language and Meaning. Edward Arnold, 1994.

Hamad, Ibnu. "Analisis Wacana (Discourse Análisis) Sebuah Pengenalan Awal." Diktat Perkuliahamn Methode Penelitian Komunikasi Kulaitatif, PPS MIK UPDM (B) Jakarta, 2007, pp. 14-15.

Hanurawan, Fattah. Psikologi Sosial: Suatu Pengantar. Remaja Rosdakarya, 2010.

Idhom, Addi M. "Update Corona 8 April 2020 Indonesia \& Data Covid-19 Dunia Hari Ini." Tirto.id, 2020. https://tirto.id/update-corona-8-april-2020-indonesia-data-covid-19-dunia-hariini-eLSN, 9 April 2020.

Ihsanuddin. "Pengumuman Mendadak Jokowi Yang Kejutkan Pasien Positif Corona." Kompas.com, 4020. https://nasional.kompas.com/read/2020/03/04/08051361/pengumuman-mendadakjokowi-yang-kejutkan-pasien-positif-corona?page=all.

jpnn.com. "Simak Pengakuan Pasien Pertama Covid-19 Di Indonesia, Sekarang Sudah Sembuh." jpnn.com, Jaringan Pemberitaan Nusantara Negeriku, 2020. https://www.jpnn.com/news/simak-pengakuan-pasien-pertama-covid-19-diindonesia-sekarang-sudah-sembuh.

Kaplan, Harold I et al. Sinopsis Psikiatri: Ilmu Pengetahuan Perilaku Psikiatri Klinis. edited by Dr. I. Made Wiguna S., Bina Rupa Aksara, 2010.

Klingemann, H.D. and A. Römmele. Public Information Campaigns and Opinion Research: A Handbook for the Student and Practitioner. SAGE Publications, 2002.

Kubler-Ross, Elisabeth. On Death and Dying. Routledge, 2009.

Pabottinggi, Mochtar. Islam, Antara Visi, Tradisi, Dan Hegemoni Bukan-Muslim. Yayasan Obor Indonesia, 1986.

Perloff, Richard M. The Dynamics of Persuasion. L. Erlbaum Association, 1993.

Piliang, Yasar Amir. Medan Kreativitas-Memahami Dunia Gagasan. Cantrik Pustaka, 2018.

Piper, Daniel. "Mcdonald's Apologises after Tasteless Logo Change." Creative Bloq Art and Design Inspiration, Creative Bloq, 25 Maret 2020. https://www.creativebloq.com/news/mcdonalds-logobacklash\#: :text=Not\%20only\%20has\%20McDonald's\%20Brazil,communities\%20in\%2 0times\%20of\%20need.

Prabowo, Dani. "Narasi Menakutkan Usai Napi Bebas Akibat Covid-19 Dan Upaya Cegah Kejahatan Berulang." Kompas.com, $15 \quad$ Maret 2020. 
https://nasional.kompas.com/read/2020/04/16/11053401/narasi-menakutkan-usainapi-bebas-akibat-covid-19-dan-upaya-cegah-kejahatan?page=all

Prireza, Adam, et al. "Daerah Bergerak Setelah Pidato Presiden - Laporan Utama." Tempo, 2020. https://koran.tempo.co/amp/laporan-utama/451025/daerah-bergerak-setelah-pidatopresiden.

Putri, Restu Diantina. "Kronologi Penularan Pasien Positif Corona Covid-19 Di Indonesia." Tirto.id, 11 Maret 2020. https://tirto.id/kronologi-penularan-pasien-positif-coronacovid-19-di-indonesia-eD6x.

Qodar, Nafiysul. "Jokowi Beri Oleh-Oleh Jamu Untuk 3 Pasien Sembuh Dari Covid-19." Liputan6.com, 16 Maret 2020. https://www.liputan6.com/news/read/4203422/jokowiberi-oleh-oleh-jamu-untuk-3-pasien-sembuh-dari-covid-19.

Rogers, Everett $\mathrm{M}$ and J. Douglas Storey. "Communication Campaign." The Handbook of Communication Science, edited by Charles R. Berger and Steven H. Chaffee, SAGE Publications, 1987, pp. 817-846. https://books.google.co.id/books?id=gH7F OkTQTEC.

Sari, Haryanti Puspa "Mensos: Pemerintah Beri Stimulus Rp 405 Triliun Untuk Penanganan Covid-19." Kompas.com, $\quad 7 \quad$ April 2020. https://nasional.kompas.com/read/2020/04/07/20070081/mensos-pemerintah-beristimulus-rp-405-triliun-untuk-penanganan-covid-19.

Thwaites, Anthony Guy et al. Tools for Cultural Studies: An Introduction. Macmillan Publ, 1999.

Umasugi, Ryana Aryadita. "Anies Terbitkan Pergub Soal Psbb Di Dki Jakarta, Diterapkan Jumat $10 \quad$ April." $\quad$ Kompas.com, 9920. https://megapolitan.kompas.com/read/2020/04/09/22340801/anies-terbitkanpergub-soal-psbb-di-dki-jakarta-diterapkan-jumat-10-april?page=all.

Venus, Antar et al. Manajemen Kampanye: Panduan Teoritis Dan Praktis Dalam Mengefektifkan Kampanye Komunikasi. Simbiosa Rekatama Media, 2004. 